\title{
THE CONTRIBUTION OF ENDOTHELIAL MARKER PROTEINS IN THE DETERMINATION OF VASCULAR ANGIOGENIC POTENTIAL, IN NORMAL PHYSIOLOGICAL CONDITIONS AND IN NEOPLASIA
}

\author{
Aneta KONWERSKA ${ }^{1}$, Beata JANIK $^{1,2}$, Agnieszka MALINSKA ${ }^{1,2}$, \\ Wojciech WITKIEWICZ ${ }^{2}$, Maciej ZABEL ${ }^{1,2}$ \\ ${ }^{1}$ Department of Histology and Embryology, University of Medical Sciences, \\ Poznan, Poland \\ ${ }^{2}$ Regional Specialized Hospital in Wroclaw, Research and Development Center, \\ Wroclaw, Poland
}

DOI: $10.2478 / \mathrm{v} 10052-011-0005-2$

\begin{abstract}
Summary: Recently, the most significant studies in the field of angiogenesis are related to trials concerning the evaluation of the prognostic significance of endothelial markers. By using an estimation of the expression of endothelial cell markers, immunohistochemical studies can assess for the continuity of the vascular intima, as well as allow for the distinction of early, late and mature forms of endothelial cells. The determination of the endothelial cell phenotype using markers such as CD34, CD31, CD133, e-NOS and von Willebrand factor may provide a valuable tool for the monitoring of both normal physiology as well as neoplastic diseases.
\end{abstract}

Key words: endothelium, angiogenesis, progenitor cells, endothelial markers (CD31, CD34, CD133, endothelial Nitric Oxide Synthase, von Willebrand factor).

\section{INTRODUCTION}

Endothelial cells are specialised flat cells that make up the endothelia, forming a uni-layered, polarised lining of the intima in blood vessels. They also act to form a tight barrier, preventing the passage of all cells and substances circulating in the blood, into the tissues [51]. Endothelial cells, apart from endothelial progenitor cells (EPCs), also comprise several subpopulations of circulating and mature endothelial cells (ECs). The cells are differentiated according to the 
presence or absence of specific surface markers. The main membrane markers of progenitor cells include antigens CD133 and CD34 as well as the vascular endothelial growth factor receptor 2 (VEGFR-2). More mature circulating cells present the phenotype of CD133(-)/CD34(+)/VEGFR-2(+). The mature endothelial cells correlate with a high expression of VEGFR-2, VE-cadherin and von Willebrand factor (vWF). Other markers of endothelial cells include CD31(PECAM) and P1H12. vWF, CD31 and VE-cadherin are present mainly in the endothelium of large blood vessels while P1H12 is typical of the endothelium of microvessels. The most reliable marker of endothelial cells is VEGFR-2, due to its occurrence in blood vessels of various calibres [24].

\section{ENDOTHELIUM - HISTOLOGICAL STRUCTURE AND SIGNIFICANCE}

The endothelium is a type of epithelium of mesodermal origin, consisting of a single layer of flat cells with elongated cell nuclei. It provides a site for several important metabolic transformations, ensuring both local and systematic haemostasis. The main functions of endothelial cells include the inhibition of blood coagulation, control of vascular wall tension, control of angiogenesis and inflammatory and immune processes. In light of the role of the epithelium in both the synthesis and release of several hormonal compounds, it may be considered to be the largest endocrine organ in the human body [54]. The principal substances released by endothelial cells include [51, 54]:

- endothelin 1 - responsible, e.g., for vasoconstriction,

- prostacyclin - responsible primarily for vasodilatation and inhibition of platelet aggregation,

- nitrogen oxide (NO) - responsible for vasodilation, inhibition of platelet aggregation and inhibition of platelet adhesion,

- von Willebrand factor (vWF) - stimulating blood coagulation and platelet adhesion,

- tissue thromboplastin and thrombomodulin - activating blood coagulation,

- interleukins (IL-2, IL-3, IL-6) - responsible for proliferation and differentiation of immune system cells,

- tissue plasminogen activator (TPA) - responsible for the control of fibrinolysis.

The endothelium contains glycosaminoglycans, integrated with proteins and lipids of the cell membrane. On the luminal side, the cell membrane is covered by a layer of glycocalyx with composed of heparin sulphate. Glycocalyx takes part in transmembrane transport, in immune processes and provides protection against free oxygen species. Moreover, it provides a vascular wall with a negative charge, permitting it to electrostatically repel negatively charged structures of cell 
membranes, morphotic blood elements and other negatively charged particles [51]. Surface glycoproteins act as cofactors in reactions of binding and activating of plasma components, and of factors released by endothelial cells. They activate antithrombin, heparin co-factor, the lipoprotein lipase, inhibitors of the exogenous clotting system and platelet factor 4. Upon analysis of the ultrastructure, endothelial cells were seen to form junctions with the assistance of cadherin 5 (CD144) and MACAM-1 (CD146) [54]. Integrin receptors are manifested in their basolateral parts, which bind the endothelium to components of the basement membrane and extracellular matrix, with collagen, glycosaminoglycans, fibronectin, elastin, vitronectin, laminin or thrombospondin. This allows for the anchorage of the endothelium to the sublayer. On the adluminal and lateral surfaces, adhesion molecules are expressed in a constitutive or induced form, including selective E (CD62E) and selective P (CD62P), which each contain fragments of lectin. Molecules of inter-cellular adhesion-1 (ICAM-1, CD54), and molecules of inter-cellular adhesion-2 (ICAM-2, CD102), vascular cell adhesion molecules-1 (Vcam-1, CD106) and platelet and endothelial cell adhesion molecules-1 (PECAM-1, CD31) are also expressed on site. They are responsible for the rolling, activation, adhesion and diapedesis of neutrophils in inflammatory processes and for intercellular interactions. The proximal, adluminal surface is generally smooth, except for a small number of microvilli formed by limiting intercellular junctions of plasma membrane [51].

An important trait of the endothelium is its ability to aggressively migrate and proliferate in response to various growth factors, e.g., vascular endothelial growth factor (VEGF) or basic fibroblast growth factor (bFGF), which leads to the formation of new vessels, or angiogenesis. Angiogenesis may develop in normal physiological conditions or in pathology (e.g., growth of solid tumours).

\section{ANGIOGENESIS}

Normal physiological angiogenesis is observed, for example, in the healing of wounds, in the genital female system of women of a reproductive age, and during implantation of an embryo into the uterine mucosa, during which the process is strictly controlled. The role of angiogenesis is particularly important in the proliferative processes of solid tumours, in which an increased blood supply allows for growth of the tumour. The process of the formation of new blood vessels starts when a neoplastic tumour reaches the diameter of around 1-3 $\mathrm{mm}$ and contains around $10^{6}$ cells. At this stage, the tumour may persist for a few months or even years and cannot continue proliferation due to an insufficient supply of oxygen and nutrients. It is only after the tumour cells develop, that an angiogenic phenotype is produced, and the appropriate growth factors are released, that the tumour may develop its own network of blood vessels and acquires the ability to 
grow further and metastasize to distant tissues [47]. Apart from neoplastic diseases, pathologic angiogenesis can be seen in conditions of hypoxia and in chronic inflammation $[7,56]$.

Angiogenesis is a multi-stage process, commencing with the stimulation of endothelial cells by various growth factors, which are released from, among other sources, the tumour itself. The principal factors which stimulate angiogenesis include vascular-endothelial growth factor (VEGF) and basic fibroblast growth factor (bFGF). The family of vascular-endothelial growth factors (VEGFs) include VEGF-A (commonly termed VEGF), VEGF-B, VEGF-C, VEGF-D, VEGF-E, VEGF-F, which interact with their specific receptors (VEGFR-1, VEGFR-2 and VEGFR-3 respectively), found exclusively on endothelial cells.

During the development of new blood vessels, the so-called endothelial progenitor cells (EPCs), originating from bone marrow, also play an important role. They develop the ability to migrate into the bloodstream and to differentiate into mature endothelial cells $[13,55]$. The process is of particular significance in neoplastic diseases, where tumour cells release SDF-1 (stroma derived factor-1), which stimulate the enhanced migration of EPCs from the bone marrow to the peripheral blood and to the sites of neoplasia. There, tumour cells begin to form new blood vessels either in the process of post-natal vasculogenesis or by the $d e$ novo formation of blood vessels from endothelial precursor cells [3, 47]. In addition to the SDF-1 protein, angiogenic factors such as VEGF, angiopoetin and erythropoetin may mobilize EPC from bone marrow to sites of an increased angiogenesis $[15,39]$. The pool of all endothelial cells in the mature human body include three subpopulations: the resting CEC (circulating endothelial cells or rCEC), i.e., the cells which form vascular wall, the activated circulating endothelial cells $(\mathrm{aCEC})$ and the endothelial cells present in bone marrow, the endothelial progenitor cells (EPCs) [16, 21]. Individual populations of cells can be identified by the presence or absence of specific surface markers.

\section{IMMUNOHISTOCHEMICAL MARKERS OF ENDOTHELIAL CELLS}

Immunohistochemical analysis of marker proteins of endothelial cells allows for an appraisal of the continuity of the intima in blood vessels, which is central to several pathological processes, including arteriosclerosis, hypertensive disease, thrombotic lesions, as well as disturbed perfusion in tissues and organs $[29,46,50]$. Nevertheless, endothelial function cannot be easily appraised in clinical conditions due to technical problems, therefore, endothelia evaluation can, in principle, only be performed in research institutes [10].

The principal (identified) markers of maturity, functional capacity and the integrity of teh endothelium include CD31, CD34, CD133, e-NOS and von 


\section{Willebrand factor.}

Antigen CD31 represents a marker recognized in the international literature as reliable for the evaluation of vascular endothelium morphologic integrity. CD31 belongs to a group of transmembrane proteins. It has a molecular weight of $130 \mathrm{kD}$, and plays a role in adhesion interactions between neighbouring endothelial cells, and between leukocytes and the endothelium. The protein belongs to the immunoglobulin superfamily termed PECAM (Platelet Endothelial Cell Adhesion Molecule) and forms attachments using both homophilic and heterophilic interactions. Expression of CD31 can be noted on the continuous endothelia of blood vessels- arteries, arterioles, veins, venules and non-sinusoid capillaries, but is absent from the continuous endothelium in areas such as in the splenic red pulp. Moreover, the dispersed expression of CD31 occurs on the surface of megakaryocytes, platelets, bone marrow cells, NK cells, and on some subgroups of lymphocyte $\mathrm{T}$ and precursors of lymphocytes B cells [32, 38].

Antigen CD34 represents another marker of blood vessel endothelia, present in most bone marrow haemopoetic cells and on epithelial cells. It is a transmembrane protein with a molecular weight of $115 \mathrm{kD}$, encoded by a gene located in chromosome 1 . The protein participates in cell adhesion and in the migration of endothelial cells during the maturation of new blood vessels. The expression of CD34 is noted in the preliminary stages of precursor cell development, at early stages of new blood vessel formation as well as during their differentiation. With the increasing maturity of EPCs, the intensity of antigen expression decreases [22].

Frequently, CD34 is used as an endothelial marker in the determination of microvessel density in neoplastic diseases [19].

CD133 represents a well known marker of stem cells. It has a molecular weight of around $120 \mathrm{kDa}$. Its amino acid sequence allowed the identification of the extracellular N-terminus, two extracellular loops, five transmembrane domains, two extensive cysteine-rich cytoplasmic loops and the cytoplasmic C-terminus. Most probably, the antigen takes part in control of stem cell growth and differentiation. Its expression develops in the early stages of haemopoetic differentiation and it decreases in line with maturation and differentiation of stem cells. No expression of the antigen can be detected on the mature cells originating from bone marrow or on mature endothelial cells [41].

The enzyme of eNOS, (or endothelial nitrogen oxide synthase), belongs to markers of the blood vessel intima, while its expression is linked to integral epithelial functions. It is one of three enzymes capable of producing nitrogen oxide (NO), and may also be able to produce superoxide anion $\left(\mathrm{O}_{2}{ }^{-}\right)$or nitrogen superoxide [60]. The enzyme, produced by endothelial cells, transforms L-arginine to L-citruline and NO. The other pathway of L-Arg metabolism involves its conversion to urea and L-ornithine by the hydrolytic enzyme of arginase [44]. Activity of vascular arginase is suspected of modulating intracellular levels of L$\mathrm{Arg}$, the factor which limits NO production by NOS. Nitrogen oxide (NO) is 
involved in the relaxation of vascular muscles through activation of cGMPdependent pathways in the smooth muscle cells of the vessels [45]. Physiologically, the two forms of nitrogen oxide synthase can be distinguished as the constitutive form (cNOS) and the inductive form (iNOS) [37]. The constitutive form, present in nervous tissue (nNOS) and in endothelial cells (eNOS), comprises up to $95 \%$ of the total synthase activity [25]. Interestingly, the nNOS isoform was discovered only a few years ago in endothelial cells. Since then, results of other studies detected the presence of nNOS in the circulatory system both in experimental animals and in humans [8, 42]. Although the functional significance of the nNOS isoform in vascular cells remains poorly recognised, several reports suggested its significance in vascular relaxation in isolated arteries $[4,5]$. It should be noted that nNOS and eNOS share a number of traits (such as constitutive expression, NO generation or calcium ion-dependent activation), and they also manifest unique traits and may play distinct roles in the function of blood vessels [26, 42]. In a similar way to eNOS, a change to a phosphorylated form determines enzymatic activity of nNOS [61]. On the other hand, little is known about phosphorylation-induced activation (Ser 1417) and the inactivation (Ser 847) of nNOS in the endothelium. In physiological conditions, the inductive form is rarely expressed, initially by the macrophages (macNOS). In mice and rat models, iNOS was shown to play a significant role in pathological mechanism of several diseases linked to inflammation [44]. This isoform takes part in the development of arterial hypertension, diabetes mellitus or myocardial infarction [12, 23, 30, 44, 53, 59]. The isoform of eNOS is present in endothelial cells lining the lumen of both the arterial or venous blood vessels, as well as in capillaries and lymphatic vessels.

VEGFR-2 serves as a receptor for the vascular endothelial growth factor (VEGF), and belongs to the family of tyrosine kinase receptors. The growth factor binds to VEGF-A, VEGF-C and VEGF-D. In adults, the receptor is expressed in the endothelial cells of blood vessels [47]. Even if the affinity of VEGF-A binding to the receptor is lower than that of VEGFR-1, it is only the VEGFR-2 which represents the principal receptor, through which endothelial cells are stimulated to proliferate. In addition to endothelial cells, the receptor is also expressed on the surface of nervous cells, osteoblasts, cells of pancreatic ducts, megakaryocytes and haemopoetic cells. Mice with a knockout of the VEGFR-2 gene die between the 8th and 9th day of foetal life due to inhibited development of haemopoetic islands and foetal blood vessels.

vWF is recognised as a marker of mature blood vessels. The antigen is involved in the development of metastases, mediating the link between tumour cells and blood platelets and, subsequently, with the endothelium. High levels of the factor were detected in an advanced stage of neoplastic disease [36]. The von Willebrand factor is a large glycoprotein, consisting of several subunits with a molecular weight ranging between $500 \mathrm{kDa}$ and over $10000 \mathrm{kDa}$. It is occurs in Weibel-Palade's bodies and in the Golgi apparatus of endothelial cells, as well as in alpha granules of megakaryocytes. This protein also plays a mediating role in the 
adhesion of thrombocytes to injured endothelium and serves as a carrier protein for factor VIII in plasma, protecting it from proteolysis. Expression of the antigen was detected in endothelial cells and megakaryocytes [11].

The abovementioned markers, expressed in the endothelium of blood vessels, constitute a proven significant diagnostic for several neoplastic diseases $[40,47]$.

\section{IMMUNOHISTOCHEMICAL EXPRESSION OF ENDOTHELIAL MARKERS IN PHYSIOLOGICAL BLOOD VESSELS AND IN NEOPLASTIC TISSUES}

The method employing mono- or polyclonal antibodies for specific proteins in a tissue allows for an objective evaluation of individual antigens in a histological material, as well as for characterising the condition and function of the studied structures. In this technique of immunohistochemistry, application of the ABC complex (avidin-biotin-peroxidase) to paraffin sections has broad applications.

As already mentioned, the development of new blood vessels involves the important role of endothelial progenitor cells (EPCs), which penetrate the vascular bed and differentiate to early, late and mature endothelial progenitor cells (Fig. 1).

Early progenitor cells are characterized by CD133, CD34 and VEGFR-2 [19]. The expression of VEGFR-2 on the surface of EPC does not disappear with the maturation of the cell, persisting on its surface until maximal differentiation is attained, i.e. until a fully mature endothelial cell is incorporated to the vascular epithelium. This may indicate that individual forms of VEGF do not only control the process of differentiation of EPCs, but also permit loosening of the intercellular links between endothelial cells, thereby permitting the migration of EPCs to the vascular bed while, in parallel, securing adhesion to the vascular wall in regions undergoing repair or neoangiogenesis [40].

The early and then later forms of circulating EPCs, gradually exhibit a diminishing expression of CD133, and increasing expression of CD31 and von Willebrand factor. The expression of the latter factor and similarly the expression of the endothelial form of nitrogen oxide synthase (eNOS), become most pronounced on mature endothelial cells, and are incorporated into the vascular wall [19]. It is worth noting that at this point, the cells no longer express CD133, while the presence of CD34 is variable. This also indicates that an analysis of the coexistence of the aforementioned markers permits the precise characterization of the type of EPC or the level of endothelium maturity. 


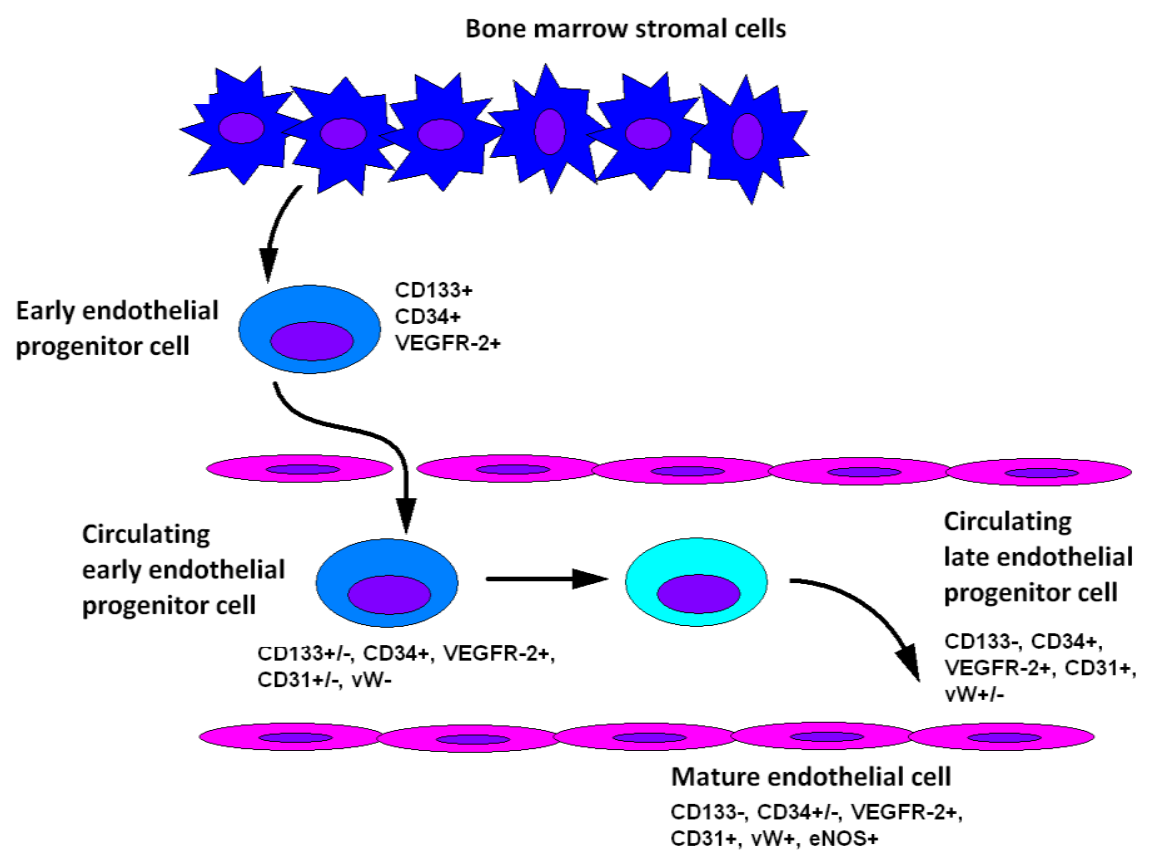

FIGURE 1. Schematic representation of recruitment, maturation and incorporation into endothelium of progenitor endothelial cells originating from the bone marrow stroma with respect to their expression of surface markers.

The process of EPC differentiation discussed above pertains to normal blood vessels. Neoplastic tissue contains a combination of blood vessels, which might differ from normal blood vessels by specific markers. Often, this results in a different function of the blood vessels. This is of particular significance for the progression of neoplastic processes, as the immature blood vessels, particularly those carrying immature intima, may be more penetrable by neoplastic cells, possibly leading to the appearance of distant metastases.

In studies conducted on sympatoblastoma, immunohistochemistry demonstrated a strong expression of $\mathrm{CD} 34$, and slightly less pronounced expression of CD31 on endothelial cells in all the examined cases. In parallel, a positive reaction for CD133 was demonstrated mainly within neoplastic infiltrates and an absence of expression of von Willebrand factor, which may point to lower maturity of the blood vessels. 


\section{MARKERS OF ENDOTHELIUM IN NEOPLASTIC DISEASES}

By employing the technique of SAGE (serial analysis of gene expression), genes coding for nine tumour endothelial markers (TEMs) were identified. The expression of these in the endothelia of blood vessels of various types of tumours and in tumours of the large intestine in particular, were significantly higher than in endothelia of healthy tissues. The expression of TEMs were confirmed by RT-PCR and in situ hybridization. Subsequent studies demonstrated that four of the markers, TEM 1, 5, 7 and 8, represent surface proteins, which now represent topics of investigation [24].

\section{Tumour endothelial marker 1}

Tumour endothelial marker 1 (TEM1, endosialin, CD248 antigen), a transmembrane glycoprotein with a molecular weight of $165 \mathrm{kDa}$, consists of 757 amino acids. It includes the $\mathrm{N}$-terminal extracellular domain and a short $\mathrm{C}$-terminal domain contained in the cytoplasm. The extracellular part of TEM1 includes a lectin-like domain, expressing common traits with thrombomodulin, Sushi/scr/ccp domain and three EGF-resembling domains. The tumour endothelial marker 1 is an orphan receptor, capable of interacting with carbohydrate molecules, with the mediation of the lectin domain. Endosialin can be identified by the FB5 monoclonal antibody, where the immunoreaction with FB5 proved to be specific for tumour microvessels, while no such a reaction was detected in normal tissues [24]. Although the mRNA for TEM1 was detected in some normal tissues, both the expression of the mRNA and the protein is much more pronounced in the various types of tumours. An increased expression of TEM1 was noted in carcinomas of large intestine, breast, lung, pancreas, urinary bladder, in glioma and melanoma, among others [31, 48]. The probable ligands of the TEM1 receptor involve collagen type I and type IV and fibronectin [48]. Experimental studies showed that an absence of TEM1 receptor expression was associated with reduced tumour growth, invasion and metastases. Moreover, an absence of TEM1 was linked to increased numbers of immature microvessels and decreased numbers of moderate and large blood vessels. This abnormal angiogenic response suggested a role of TEM1 in the control of interactions between tumour cells, endothelial cells and matrices [24]. Endosialin was found to cause no expression on the surface of glioma endothelial cells but was present on pericytes [43] and on neoplastic myofibroblasts [6]. In 2008, an attempt was made to identify extracellular ligands of TEM1. The specific ligand was found to involve the protein linked to the development of metastases, Mac-2 BP/90K. Its C-terminal fragment contains binding sites for galectin 3 and collagen, as structures responsible for the binding of endosialin [2]. Thus, new interactions were identified between endosialin on stromal fibroblasts and Mac-2 BP/90K, present on tumour cells [24]. Analysis of 
Mac-2 BP/90K expression in vivo demonstrated that it was scarce or absent in most normal tissues, but it was strongly pronounced in human neoplastic tissues.

\section{Tumour endothelial marker 5}

TEM5 belongs to the family of transmembrane proteins, and is linked to $\mathrm{G}$ protein in its receptor function, consisting of 1331 amino acids. Its augmented expression in endothelial cells develops during both normal physiological and neoplastic angiogenesis. The transmembrane domain of TEM5 resembles CELsr1 proteins, which are linked to cadherin and the family of calcium-independent $\alpha$ latrotoxin receptors. The structure of the receptor suggests that it belongs to GPCR ( $G$ protein-coupled receptors) class II receptor family, which are responsible for the transmission of a cellular signal. The respective ligands include peptides, such as calcitonin or secretin, which activate signalling cascades of adenylate cyclase and inositol phosphate. Thus, TEM5 may transmit signals to the cellular interior [24]. The extracellular domain represents a complete soluble fragment of TEM5 (sTEM5) which is released depending on the level of activity of the endothelial cell-formed network of capillaries controlled by the growth factors. Proteolytic transformation of the surface of sTEM5 by MMP-9, uncovers the binding site for $\alpha v \beta 3$ integrin. The adhesion of the endothelial cells to sTEM5 promotes their survival [49].

\section{Tumour endothelial marker 7}

Tumour endothelial marker 7 (TEM7, TEM3, PLXDC1 - plexin domain containing 1) occurs in the cell membrane and has receptor activity. TEM7 is a transmembrane protein with an extensive extracellular domain, hydrophobic transmembrane domain and a short cytoplasmic domain [18]. There is an extracellular region comprising the plexin-resembling domain and the nidogenresembling domain $[24,58]$. They participate in protein-protein integration. It is generally known that the main function of nidogen (entactin) involves the binding of non-collagen components of the basement membrane with fibres of collagen IV, which are most likely, also involved in cellular adhesions. A few variants of TEM7 can be detected in the neoplastic endothelium, including the intracellular (TEM7-I) and secretory (TEM7-S) forms and forms occurring on the surface of the cell membrane (TEM7-M) [24]. TEM7 appears to represent the gene encoding surface proteins of human tumour endothelia which are most frequently expressed [18]. Both the protein and mRNA of TEM7 result in an increased expression of various solid tumours in the endothelia, including carcinomas of the brain, breast, large intestine, lung [30] and in osteogenic sarcomas [14, 18]. It provides an opportunity for TEM7-targeted anti-angiogenic therapy, as the physiological ligand of TEM7 and TEM7R, cortactin has been identified. The domain binding the receptors is composed of a nine amino acid sequence located just behind the SH3 domain. Cortactin is a protein present in the cytoplasm of various cell types. The discovery 
of the ligand allowed for the possibility of synthesizing low molecular weight compounds targeted at the endothelium of neoplastic blood vessels [24]. A positive correlation was documented between the expression of TEM7 and the intensity of angiogenesis in vitro, as well between the inhibitory effect of siRNA for TEM7 in proliferation, and the migration of endothelial cells. Therefore, it is likely that TEM7 plays an important role in angiogenesis as proliferation and migration represent key stages in the process [14].

\section{Tumour endothelial marker 8}

Tumour endothelial marker 8 (TEM8, anthrax toxin receptor - ATR, ANTXR1) represents a membrane protein consisting of 564 amino acids, which is highly specific for angiogenesis in neoplastic tissue. Studies report that its expression is absent or negligible in the endothelia of healthy tissues and the proliferating corpus luteum. The protein is a receptor for a toxin produced by Bacillus anthracis (anthrax bacterium). Its extracellular region contains von Willebrand factor domain type A, frequently present in extracellular domains of integrins. The cytoplasmic portion of TEM8 consists of 220 amino acids and is significantly larger than corresponding portions of remaining TEMs. It contains at least seven potential sites for phosphorylation, which is consistent with the hypothesis concerning the involvement of TEM8 in the transmission of signals controlling tumour-typical angiogenesis. TEM8 stimulates endothelial cells in the migration, adhesion and formation of capillaries [17].

Some studies indicate that the soluble ectodomain of the TEM8 receptor represents the adhesion molecule binding collagen type I, gelatin, and the $\alpha 3$ subunit of collagen type VI [41]. This, in turn, suggests interactions of the receptor with molecules of the extracellular matrix.

Three isoforms of the receptor include the long, short and moderate length forms, with only the first and the last form containing the vWF A domain [24].

Several independent investigators demonstrated that TEM8 is extensively expressed in endothelial cells of colonorectal carcinoma. The natural ligand for TEM8 proved to be the collagen $\alpha 3$ subunit, which manifests as one of very few among 32500 analysed transcripts, in overexpression in the neoplastic endothelium [24].

TEM8 may also prove useful in the identification of neoplastic microvessels in breast cancer, while its augmented expression is linked to progression of the disease [9]. Thus, TEM8 appears to provide a useful target for anti-neoplastic therapy. 


\section{SUMMARY}

In the last ten years significant progress has been made, not only in novel or modified research techniques, but also in the recognition of new biological properties of neoplastic cells and precursor cells of blood vessels developing in the neoplastic tissue.

Currently, the evaluation of blood vessel density in the neoplastic tissue carries a definite diagnostic and prognostic significance [33]. Using various antibodies, the endothelium is labelled and the microvessel density (MVD) can be evaluated [35]. In an increasingly broad range of neoplastic diseases, microvessel density has been proven to correlate with the failures of treatment.

Also, the maturity of endothelial cells, evaluated by the expression of surface markers was found to be inversely proportional to their permeability and, thus, to the potential for the penetration of tumour cells into the vascular bed and the production of distant metastases [19]. Therefore, it appears an evaluation of endothelial cell maturity in blood vessels of a tumour, using the expression of surface markers, may be helpful in defining the advancement of the neoplastic disease, and in the prognosis of the disease, in combination with the already standard testing of microvessel density.

\section{ACKNOWLEDGEMENTS}

This work is supported by European Regional Development Fund and the Polish Government (Operational Programme Innovative Economy 2007-2013) under the grant 'WROVASC — Integrated Cardiovascular Centre'.

\section{REFERENCES}

[1] BARAŃSKA P, JERCZYŃSKA H, PAWŁOWSKA Z. Czynnik wzrostu śródbłonka naczyń - budowa i funkcje. Postępy Biochem 2005; 51: 13-21.

[2] BECKER R, LENTER MC, VOLLKOMMER T, BOOS AM, PFAFF D, AUGUSTIN HG CHRISTIAN S. Tumor stroma marker endosialin (Tem1) is a binding partner of metastasis - related protein Mac-2 BP/90K. FASEB J 2008; 22: 3059-67.

[3] BERGRES G, BENJAMIN L. Tumorigenesis and the angiogenic switch. Net Rev Cancer 2003; 3 (6): 401-410.

[4] CAPETTINI LS, CORTES SF, GOMES MA, SILVA GA, PESQUERO JL, LOPES MJ, TEIXEIRA MM, LEMOS VS. Neuronal nitric oxide synthase-derived hydrogen peroxide is a major endothelium-dependent relaxing factor. Am J Physiol Heart Circ Physiol 2008; 295: H2503-H2511.

[5] CHAN YC, LEUNG FP, WONG WT, TIAN XY, YUNG LM, LAU CW, TSANG SY, YAO X, CHEN ZY, HUANG Y. Therapeutically relevant concentrations of raloxifene dilate pressurized rat resistance arteries via calcium-dependent endothelial nitric oxide synthase activation. Arterioscler Thromb Vasc Biol 2010; 30: 992-999. 
[6] CHRISTIAN S, WINKLER R, HELFRICH I, Boos AM, BESEMFELDER E, SCHADENDORF D, AUGUSTIN HG. Endosialin (Tem1) is a marker of tumor-associated myofibroblasts and tumor vessel-associated mural cells. Am J Pathol 2008; 172: 486-94.

[7] CIERNIEWSKI CS. Regulacja angiogenezy - nowa broń onkologii. Biol Molek 2006; 1 (5): 20-22.

[8] DANESHTALAB N, SMEDA JS. Alterations in the modulation of cerebrovascular tone and blood flow by nitric oxide synthases in SHRsp with stroke. Cardiovasc Res 2010; 86: 160-168.

[9] DAVIES G, RMALI KA, WATKINS G, MANSEL RE, MASON MD, JIANG. Elevated levels of tumour endothelial marker-8 in human breast cancer and its clinical significance. Int J Oncol 2006 29: $1311-7$.

[10] DEANFIELD JE, HALCOX JP, RABELINK TJ. Endothelial function and dysfunction: testing and clinical relevance. Circulation 2007; 115 (10): 1285-1295.

[11] DENIS CV. Molecular and cellular biology of von Willebrand factor. Int J Hematol 2002; 75: 3-8.

[12] DIAS FA, URBONIENE D, YUZHAKOVA MA. Ablation of iNOS delays cardiac contractile dysfunction in chronic hypertension. Front Biosci 2010; 2: 312-24.

[13] DIGNAT-GEORGE F, SAMPOL J. Circulation endothelial cells in vascular disordes: new insights into an old concept. Eur J Haematol 2000; 65: 215-220.

[14] FUCHS B, MAHLUM E, HALDER C. High expression of tumor endothelial marker 7 is associated with metastasis and poor survival of patients with osteogenic sarcoma. Gene 2007; 399: 137-43.

[15] FÜRSTENBERGER G, VON MOOS R, LUCAS R, THÜRLIMANN B, SENN H, HAMACHER J, BOENEBERG EM: Circulating endothelial cells and angiogenic serum factors during neoadiuvant chemotherapy of primary breast cancer. Br J Cancer 2006; 94: 524-531.

[16] GOOK PK, LIP GY, BOOS CJ, STONELAKE PS, BLANN AD. Circulating endothelial cells, endothelial progenitor cells, and endothelial microparticles in cancer. Neoplasia 2006; 8 (2): 79-88.

[17] HAI-FENG D, XIAN-WEN H, JIN-LONG C, LI-HUA G. Antitumor Activities of TEM8-Fc: An Engineered Antibody-like Molecule Targeting Tumor Endothelial Marker 8. J Natl Cancer Inst 2007; 99 (20): 1551-1555.

[18] HALDER C, OSSENDORF C, MARAN A, YASZEMSKI M, BOLANDER ME, FUCHS B, SARKAR G. Preferential Expression of the Secreted and Membrane forms of Tumor Endothelial Marker 7 transcripts in Osteosarcoma. Anticancer Res 2009; N; 29 (11): 4317-4322.

[19] HRISTOV M, WEBER C. Endothelial progenitor cells: characterization, pathophysiology and possible clinical relevance. J Cell Mol Med 2004; 8 (4): 498-508.

[20] KHNYTKIN D, TROEN G, BERNER JN. The expression of fibroblast growth factors and their receptors in Hodgkin's lymphoma. J Pathol 2006; 208 (3): 431-438.

[21] KLUZ J, ADAMIEC R. Krążące komórki śródbłonka w zapalnych chorobach naczyń. Adv Clin Exp Med 2007; 16 (1): 95-104.

[22] KRAUSE DS, FACKLER MJ, CIVIN CI, MAY WS. CD34: structure, biology, and clinical utility. Blood 1996 ; 1: 87 (1): 1-13.

[23] LEE JH, PALAIA T, RAGOLIA L. Impaired insulin-mediated vasorelaxation in diabetic GotoKakizaki rats is caused by impaired Akt phosphorylation. Am J Physiol Cell Physiol 2009; 296: C327-38.

[24] KOPCZYŃSKA E. Śródbłonkowe markery nowotworowe. Współczesna Onkologia 2008; 12, 6 $255-260$.

[25] LEKONSTEVA O, CHAKRABARTI S, JIANG Y, CHEUNG CC, DAVIDGE ST. Role of Neurona Nitric Oxide Synthase in Estrogen-Induced Relaxation in Rat Resistance Arteries. J Pharmacol Exp Ther 2011. JPET Fast Forward. Published on August 1, 2011 as DOI:10.1124/jpet.111.183798

[26] MELIKAN N, SEDDON MD, CASADEI B, CHOWIENCZYK PJ, SHAH AM. Neuronal nitric oxide synthase and human vascular regulation. Trends Cardiovasc Med 2009; 19: 256-262.

[27] MEREGALLI M, FARINI A, BELICCHI M, TORRENTE Y. CD133(+) cells isolated from various sources and their role in future clinical perspectives. Expert Opin Biol Ther 2010; 10 (11): 1521-8.

[28] MIZIA-MALARZ M, SOBOL G, WOŚ H. Angiogeneza w przewlekłych schorzeniach zapalnych nowotworowych. Pol Merkuriusz Lek 2008; XXIV, 141: 185-189.

[29] MOZAFFARIAN D, WILSON PW, KANNEL WB. Beyond established and novel risk factors: lifestyle risk factors for cardiovascular disease. Circulation 2008; 117 (23): 3031-3038.

[30] NAGAREDDY PR, SOLIMAN H, LIN G. Selective inhibition of protein kinase C beta(2) attenuates inducible nitric oxide synthase-mediated cardiovascular abnormalities in streptozotocin-induced 
diabetic rats. Diabetes 2009; 58: 2355-64.

[31] NANDA A, KARIM B, PENG Z. Tumor endothelial marker 1 (TEM1) functions in the growth and progression of abdominal tumors. PNAS 2006; 103: 3351-6.

[32] NEWMAN PJ, ALBELDA SM. Cellular and molecular aspects of PECAM-1. Nouv Rev Fr Hematol 1992; 34 Suppl: S9-13.

[33] NICO B, BENAGIANO V, MANGIERI D, MARUOTTI N, VACCA A, RIBATTI D. Evaluation of microvascular density in tumors: pro and contra. Histol Histopathol 2008 May; 23 (5): 601-7.

[34] NOWICKI M, MISTERSKI M, MALINSKA A, PEREK B, OSTALSKA-NOWICKA D, JEMIELITY M, WITKIEWICZ W, ZABEL M. Endothelial integrity of radial artery grafts harvest by minimally invasive surgery - immunohistochemical studies of CD 31 and endothelial nitric oxide synthase expression: a randomized trial. Eur J Cardiothorac Surg 2011; 39: 471-477.

[35] OWOC-LEMPACH J, CHYBICKA A. Znaczenie angiogenezy w nowotworach występujących w populacji dziecięcej. Onkol Pol 2006; 9 (3): 87-92.

[36] PADUCH R. Przerzut nowotworowy - znaczenie agregacji komórek nowotworowych z płytkami krwi. Onkol Pol 2005; 8, 4: 229-238.

[37] PAUTZ A, ART J, HAHN S. Regulation of the expression of inducible nitric oxide synthase. Nitric Oxide 2010; 23: 75-93.

[38] PRIVRATSKY JR, PADDOCKCM, FLOREY O, NEWMAN DK, MULLER WA, NEWMAN PJ. Relative contribution of PECAM-1 adhesion and signaling to the maintenance of vascular integrity. J Cell Sci 2011; 124: 1477-85.

[39] RIBATTI D. The involvement of endothelial progenitor cells in tumor angiogenesis.: J Cell Mol Med, 2004; 8: 294-300.

[40] RIBATTI D, MARIMPIETRI D, PASTORINO F, BRIGNOLE C, NICO B, VACCA A, PONZONI M. Angiogenesis in Neuroblastoma. Ann NY Acad Sci 2004; 1028: 133-142.

[41] SAGRINATI C, NETTI GS, MAZZINGHI B, LAZZERI E, LIOTTA F, FROSALI F, RONCONI E, MEINI C, GACCI M, SQUECCO R, CARINI M, GESUALDO L, FRANCINI F, MAGGI E, ANNUNZIATO F, LASAGNI L, SERIO M, ROMAGNANI S, ROMAGNANI P. Isolation and characterization of multipotent progenitor cells from the Bowman's capsule of adult human kidneys. J Am Soc Nephrol 2006; 17 (9): 2443-56.

[42] SEDDON M, MELIKIAN N, DWORAKOWSKI R, SHABEEH H, JIANG B, BYRNE J, CASADEI B, CHOWIENCZYK P, SHAH AM. Effects of neuronal nitric oxide synthase on human coronary artery diameter and blood flow in vivo. Circulation 2009; 119: 2656-2662.

[43] SIMONAVICIUS N, ROBERTSON D, BAX DA, JONES C, HUIJBERS IJ, ISACKE CM. Endosialin (CD248) is a marker of tumor-associated pericytes in high-grade glioma. Mod Pathol 2008; 21: 308-15.

[44] SKÓRA J, BIEGUS J, PUPKA A, BARĆ P, SIKORA J, SZYBER P. Molekularne podstawy angiogenezy. Postępy Hig Med Dośw 2006; 60: 410-415.

[45] SOSKIĆ SS, DOBUTOVIC BD, SUDAR EM, OBRADOVIĆ MM, NIKOLIĆ DM, DJORDJEVIC JD, RADLAK DJ, MIKHAILIDIS DP, ISENOVIĆ ER. Regulation of Inducible Nitric Oxide Synthase (iNOS) and its Potential Role in Insulin Resistance, Diabetes and Heart Failure. Open Cardiovasc Med J 2011; 5: 153-163.

[46] SUDAR E, DOBUTOVIC B, SOSKIE S. Regulation of inducible nitric oxide synthase activity/expression in rat hearts from ghrelin-treated rats. The Open Cardiovascular Medicine Journal 2011; 5: 153-163.

[47] SUGIURA T, DOHI Y, TAKASE H, YAMASHITA S, TANAKA S, KIMURA G. Increased reactive oxygen metabolites is associated with cardiovascular risk factors and vascular endothelial damage in middle-aged Japanese subjects. Vasc Health Risk Manag 2011; 7: 475-482.

[48] ŚWIDZINSSKA E, NAUMNIK W, CHYCZEWSKA E. Angiogeneza i neoangiogeneza - znaczenie w raku płuca i innych nowotworach. Pneumonol Alergol Pol 2006; 74: 414-420.

[49] TOMKOWICZ B, RYBINSKI K, FOLEY B. Interaction of endosialin/TEM1 with extracellular matrix proteins mediates cell adhesion and migration. PNAS 2007; 104: 17965-70.

[50] VALLON M, ESSLER M. Proteolytically processed soluble tumor endothelial marker (TEM) 5 mediates endothelial cell survival during angiogenesis by linking integrin alpha(v)beta3 to glycosaminoglycans. J Biochem 2006; 281 (45): 34179-88.

[51] VANHOUTTE PM, SHIMOKAWA H, TANG EH, FELETOU M. Endothelial dysfunction and 
vascular disease. Acta Physiol Hung 2009; 196 (2): 193-222.

[52] WALSKI M, FRONTCZAK-BANIEWICZ M. Cechy ultrastrukturalne prawidłowego dysfunkcyjnego śródbłonka naczyń krwionośnych. Pol Arch Med Wewn 2007; 117 (Supl.): 46-49.

[53] WERNER E, KOWALCZYK AP, FAUNDEZ V. Anthrax toxin receptor 1/tumor endothelium marker 8 mediates cell spreading by coupling extracellular ligands to the actin cytoskeleton. J Biol Chem 2006; 281: 23227-36.

[54] WHITE AR, RYOO S, LI D. Knockdown of arginase I restores NO signaling in the vasculature of old rats. Hypertension 2006; 47: 245-51.

[55] WNUCZKO K, SZCZEPAŃSKI N. Śródbłonek-charakterystyka i funkcje. Pol Merkuriusz Lek 2007; XXIII, 133: 60-65.

[56] WOYWODT A, BAHLMANN F, DE GROOT K, HALLER H, HAUBITZ M. Circulation endothelial cells: life, death, detachment and repair of the endothelial cell layer. Nephrol Dial Transplant 2002; 17: 1728-1730.

[57] WRÓBEL T, MAZUR G, DZIĘGIEL P. Density of intranodal lymphatics and VEGF-C expression in B-cell lymphoma and reactive lymph nodes. Folia Histochem Cytobiol 2006; 44: 43-47.

[58] WRÓBEL T., PORĘBA M., MAZUR G. Angiogenic and coagulation - fibrinolysis factors in nonHodgkin's lymphoma. Neoplasma 2006; 53: 253-258.

[59] YUAN J, OSSENDORF C, SZATKOWSKI JP, BRONK JT, MARAN A, YASZEMSKI M, BOLANDER ME, SARKAR G, FUCHS B. Osteoblastic and osteolytic human osteosarcomas can be studied with a new xenograft mouse model producing spontaneous metastases. Cancer Invest 2009; 27: 435-442

[60] ZAKULA Z, KORICANAC G, PUTNIKOVIC B, MARKOVIC L, ISENOVIC ER. Regulation of the inducible nitric oxide synthase and sodium pump in type 1 diabetes. Med Hypotheses 2007; 69: 302306.

[61] ZHANG P, XU X, HU X. Inducible nitric oxide synthase deficiency protects the heart from systolic overload-induced ventricular hypertrophy and congestive heart failure. Circ Res 2007; 100: 1089-98.

Corresponding author: Aneta Konwerska

Department of Histology and Embryology

Poznan University of Medical Sciences

Swiecicki Str. 6

60-781 Poznan, Poland

phone +48618546446

fax. +48618546440

e-mail: akonwer@ump.edu.pl 